\title{
Human Capital Formation Programmes and Organizational Commitment among Industrial Workers in South -West Nigeria
}

\author{
Dayo Idowu Akintayo \\ Dept. of Human Resource Development, College of Management and Social Sciences, Osun \\ State University, Okuku Campus, Nigeria. \\ E-mail: pastordayoakin@yahoo.com
}

Accepted: September 05, 2012 Published: October 10, 2012

Doi:10.5296/ijhrs.v2i4.2516 URL: http://dx.doi.org/10.5296/ijhrs.v2i4.2516

\begin{abstract}
The study investigated the impact of human capital formation programmes on organizational commitment of workers in industrial organizations in South-Western Nigeria. This study adopted ex-post-facto research method. A total of 240 respondents were selected for the study using proportionate stratified sampling technique.

The Human Capital Formation Scale (HCFS) with three subset scales which include: Computer Skill Training Scale (CSTS) and Conflict Management Skill Training Scale (CMSTS) and Organizational Commitment Scale (OCS) was used for data collection.

However, the research questions generated for the study were tested using Regression Analysis and t-test statistical method at 0.05 alpha levels. The finding of the study revealed that the human capital formation programmes (taken together) significantly influenced organizational commitment of workers. Also, finding revealed that computer skill training and conflict management skill training have significantly influenced organizational commitment of workers. It was found that there is no significant difference between male and female employees exposure to each of the human capital formation programmes. The finding further showed that there was no significant difference in the level of both male and female workers` participation in human capital formation programmes in both public and private organizations selected for the study. Based on the findings of the study, it is recommended that human capital formation programmes should be given priority by all establishments in order to forestall organizational commitment for all levels of workers. Also, training needs of the organization as well as that of workers must be identified before making recommendations for training. Moreover, human resource development policies should be well defined and be entrenched in the mission statement of all work organizations in Nigeria, in order to foster equity and promotional skill acquisition.
\end{abstract}




\section{Introduction}

Human capital has been perceived as the most salient asset upon which the success or failure of organizations revolved. Collins (2010) posits that human capital refers to the composition and quality of the workforce. Human capital formation as strategy for improving the skill, knowledge and orientation of workforce has attracted attentions of organizational behaviourists and human resource management practitioners in the recent times. Human capital formation according to Odia (2007), Kerr (2001), Akintayo (2007) and Willington (2003) is the process of building the human skills, the work habits and the capacity for productive employment. The term human capital formation is often been interchangeably used to denote manpower or human resource development. However, the totality of acquisition of knowledge, skills and activities be it for specific or immediate use, or for general and future purpose is adopted for the study

Akintayo (2009) and Kingsley (2011) submit that the world is not a stagnant and the technological innovations vis-à-vis the overall turbulent changing work environments are becoming a recurring phenomenon. As such, workers in work organizations need to update their knowledge, skills and attitudes to function effectively and to keep to the pace of new methods of production, human relations, improvement in their world view and communication system. This submission serves as inspiration and justification for this present study.

Basically, human capital formation activities are means of attaining organizational goal and desired results. Caleb (2010) contends that employers at times are partly responsible for stating the objectives of most human capital formation programmers in terms of reduced turnover, reduced costs, improved efficiently, increased in quality and quantity of production, reduction in grievances or improved morale. Olaniyi (2010) reported that truly, the human capital formation, as a form of manpower development programme, had significantly influenced achievement of organizational goals, nevertheless, it is at times difficult to determine its contributions to organizational goals, hence the need to evaluate human capital formulation programmes in terms of reaction, learning and behaviour that tend to affect workers`attitude to work.

Various studies on human capital formation in forms of manpower development and training have been carried out within and outside Nigeria regarding the impact of training progammes on the productivity and performance of workers as well as workers 'attitude to work. For instance, Hassan (1997), Shimry and Leohard (2002), Akintimile (2002) and Kingsley (2011) reported that there was a significant relationship between manpower development programmes and skill utilization, improved morale, increase productivity and development of technology competence in workers. In a related study, Phillips and Thomas (2007) reported a positive influence of training programmes on job stability and wage increment, especially when they obtained job relevant to the skills acquired.

Reflecting on the viability of on the job (in - company training) and off - the job (institutional training) as atypical human capital formation programmes, Kenny (2011) and Kolawole (2010) reported that on-the job training participants were more successful in terms of efficiency and effectiveness on the job than graduates of institutional training programmes. 
This finding is most without a limitation, for the success of trainees seems to be primarily influenced by the type or form organization in which they work and other environmental factors. This finding therefore calls for further investigation, hence this study.

In all work organizations either private or public, employers have realized the need for constant improvement and development of their workforce in order to meet challenges posed by the changes in the taste of customers and technological innovations. Actually, the recourses at the disposal of organizations vary and these dictate the ability to have the best manpower and train employees towards achieving effectiveness on their job vis-a-vis organizational productivity (Williams, 2010).

Cole (2011) submits that a well trained labour force is a result of having enough resources, financial and materials, to maintain a large training department which can identify the training needs of workers and as such take necessary action either by organizing on-the-job training or sending the workers to attend training programmes elsewhere. Akintayo (2009) contends that economic returns in terms of increase in productivity often results from manpower development and training. This implies that in a market economy, like Nigeria, this increment in output will in turn be reflected by higher earnings accruing to the organization and individual workers due to their increased productivity fostered by human capital formation programmes.

Kerr (2001), Akintayo (2009) and Olaniyi (2010) reported that human capital formation progammes, which could take different forms, length and contents were cost effective in training workers for semi- skilled and skilled occupation. Similarly, Friar (2004) reported the private and social costs with or without wastage; as per completion of industrial training programmes was more cost effective than formal education. This indicates that the amount of monies, time and energy expended on workers training were justified by the productive level of the participating workers.

Organizational commitment or job commitment refers to the degree of identification an individual employee has with the vision and mission statements of an organization. Organizational commitment is defined as the degree to which the employee feels devoted to their organization (Spector, 2000). Thus, organizational commitment has become one of the most popular work attitudes studied by practitioners and researchers (Meyer, Allen \& Smith, 1993; Mowday, Porter, \& Steers, 2003). One of the main reasons for its popularity is that organizations have continued to find and sustain competitive advantage through teams of committed employees. Meyer, Gellatley, Goffin \& Jackson, (2000) have found that committed employees are more likely to remain with the organization and strive towards the organization's mission, goals and objectives. Further research into this variable has concluded that commitment is a diverse construct.

Meyer and Allen (2003) submit that there is general acceptance that organizational commitment has three main facets: affective, continuance, and normative, each with its own underlying 'psychological states'. According to Meyer and Allen affective commitment refers to the emotional bond and the identification the employee has with the organization. For the employees the positives include enhanced feelings of devotion, belongingness, and stability. The authors argue further that continuance (economic/calculative) commitment refers to what the employee will have to give up if they have to leave the organization or in other terms, the 
material benefits to be gained from remaining. Employees whose primary link to the organization is based on continuance commitment remain with the organization because they feel they need to do so for material benefits. Therefore, if the employees believe that fewer viable alternatives are available their continuance commitment will be stronger to their current employer. Lastly, normative commitment or moral commitment (Jaros, Jermier, Koehler, \& Sincich, 2003) reflects a feeling of obligation to continue employment. Employees with a high level of normative commitment feel that they ought to remain with the organization (Bentein, Vandenberghe \& Stinglhamber, 2005). Jaros et al (2003) argue that the commitment is determined by being obligated to work in the organization, a sense of moral obligation following their parents, who may have been long-term employees of the organization therefore, a sense of duty to belong.

All the literature reviewed above established human capital formation in terms of manpower development and training as footstep to productivity bargaining in work organizations. These studies have contributed to the on-going research in that it revealed positive relationship between human capital formation and improved performance on the job, attitude to work as well as wages increment. However, the studies reviewed in this study have not examined the relevance of human capital formation to organizational commitment among industrial workers, the gap in the existing literature, which this study is designed to fill and virtually expand the frontier of knowledge.

\subsection{Statement of the Problem}

The study investigated the impact of human capital formation programmes on organizational commitment of workers in industrial organizations in South-Western Nigeria. .This is for the purpose of establishing the relevance of human capital formation programmes to continuance commitment of workers to organizational goal achievement in Nigeria.

\subsubsection{Objectives of the Study}

Specifically, the objectives of the study are to

1) Determine the combined influence of human capital formation programmes (Computer skill training and Conflict management skill training) on organizational commitment of industrial workers in South-Western Nigeria

2) Ascertain the strength of causation of predictor variables (human capital formation programmes) on organizational commitment of workers

3) Determine the gender difference in exposure of respondents to human capital formation programmes

4) Find out the difference in exposure of respondents to human capital formation programmes in public and private organizations?

5) Ascertain the gender difference in organizational commitment on the basis of exposure of respondents to human capital formation programmes? 


\subsubsection{Research Questions}

1) What is the combined influence of human capital formation programmes

(Computer skill training and Conflict management skill training) on organizational commitment of workers?

2) What is the strength of causation of predictor variables (human capital formation programmes) on organizational commitment of workers?

3) Is there any significant gender difference in exposure of respondents to human capital formation programmes?

4) Is there any significant difference in exposure of respondents to human capital formation programmes in public and private organizations?

5) Is there any significant gender difference in organizational commitment on the basis of exposure of respondents to human capital formation programmes?

\subsection{Methodology}

\section{Design}

This study adopted ex-post-facto research method to establish the relative and combined influence of human capital formation programmes on organizational commitment of industrial workers in South-Western Nigeria .The ex-post-facto design is appropriate for the study since it could affords the researcher collecting data without manipulating any of the variables of interest in the study.

\subsubsection{Participants}

There respondents were selected from both private and public organizations in South-Western Nigeria .The selected industrial organizations include Nigerian Breweries Plc, First Bank of Nigeria Plc, Nigerian Postal Agency Plc, and Power Holding of Nigeria Plc. These organizations usually organized training programmes for their workers irrespective of their levels of education, once they are employed.

However, all employees in these organizations formed the population for the study. A total of 240 respondents were selected for the study using proportionate stratified sampling technique. The stratified sampling technique was used to select respondents on the basis of the two strata of organization (Private and Public) and gender (male and female). Also, the proportionate sampling method was adopted for sample selection on the basis of population. Moreover, $144(60.3 \%)$ male respondents and $96(39.7 \%)$ female respondents participated in the study. The age range of the respondents was from 26-65 years with mean age of 18.35 and standard deviation of 8.78.

\subsubsection{Research Instruments}

Three sets of questionnaire used for data collection. These include: Human Capital Formation Scale (HCFS) with three subset scales which include: Computer Skill Training Scale (CSTS) and Conflict Management Skill Training Scale (CMSTS) and Organizational 
Commitment Scale (OCS).

\subsubsection{Human Capital Formation Scale (HCFS)}

Human Capital Formation Scale (HCFS) developed by Akintayo (2009) contains 11 items relating to human skill development. The scale was divided into section A and B. Section A contains 6 items concerning the personal demographic information about the respondents. For instance: Name of organization, marital status, age, sex, highest educational qualification, working experience etc.

Section B contains 11 items relating to human capital formation programmes, its relevance and respondents ` pattern of participation. For instance: You often participate in human capital formation programmes; Skills acquired through human capital formation programmes has impacted your job commitment, Your organization often responsible for your participation $\mathrm{n}$ in human capital formation programmes, You often participate in on-the-job human capital formation programmes, You often participate in off-the-job human capital formation programmes, etc. The author reported reliability co-efficient of 0.78 . For the present study, the researchers obtained alpha co-efficient of 0.85 . The response format was a modified four point Likert type rating scale ranging from (1=Strongly Disagree to $4=$ Strongly Agree).

\subsubsection{Computer Skill Training Scale (CSTS)}

The CSTS developed by Collins (2010) contains 17 items relating to computer manipulation skill training as it affects organizational commitment of the workers. It was divided into section A and B. Section A contains 6 items concerning the personal bio-data of the respondents. For instance: Name of organization, marital status, age, sex, highest educational qualification, working experience etc.

Section B contains 11 items, which focus on relationship of workers` participation in computer skill training programme and their organizational commitment. For instance, in your organization, participation in computer manipulation skill training programme has fostered: workers` identification with organizational goals, sharing the vision of the organization, devoted to organizational goal achievement, loyalty to organization, job retention, assurance of continuous membership of the organization, etc. The author reported reliability co-efficient of 0 . 87. For the present study, the researchers obtained alpha co-efficient of 0.88 . The response format was a modified four point Likert type rating scale ranging from ( $1=$ Strongly Disagree to $4=$ Strongly Agree).

\subsubsection{Conflict Management Skill Training Scale (CMSTS)}

The CMSTS developed by Akintayo (2009) contains 18 items relating to conflict management skill training as it affects organizational commitment of the workers. This scale was modified by the researchers. It was divided into section A and B. Section A contains 6 items relating to the demographic information about the respondents. For instance: Name of organization, marital status, age, sex, highest educational qualification, working experience, etc.

Section B contains 12 items which focused on relationship of conflict management skill training and organizational commitment of the workers. For instance, in your organization, 
participation in conflict management skill training programmes has fostered: commitment to organizational goal achievement, total devotion of time and energy to organizational activities, workers`constant identification with organization, sharing the vision and mission statement of organization, loyalty to organization, cordial interpersonal relations at workplace, etc. The author reported reliability co-efficient of 0.81 . For the present study, the researchers obtained alpha co-efficient of 0.83 . The response format was a modified four point Likert type rating scale ranging from ( 1 - Strongly Disagree to $4=$ Strongly Agree $)$.

\subsubsection{Organizational Commitment Scale (OCS)}

The OCS is based on a 10-item scale developed by Kingsley (2000) but was modified by the researcher for measuring the organizational commitment of the workers. The author divides the scale into two subdivisions, affective and continuance commitment. Affective commitment has eight items, for example, "I enjoy discussing my organization with people outside it". Continuance commitment has eight items, for example, "right now, staying with the organization is a matter of necessity as much as desire". The items are measured on a Likert type anchored scale from = strongly disagree (1), to = strongly agree (7). The Cronbach's alpha for organizational commitment in this sample was affective commitment 0.78 and continuance commitment 0.81 . But for the present study; the researchers reported Cronbach reliability co-efficient of 0.81 for affective commitment and 0.87 for continuance commitment.

\subsubsection{Procedure}

The researcher administered the measuring scales, which guarantee anonymity of the respondents, personally with the assistance of three trained research assistants. The researcher consulted with the Director of Human Resource Management in each of the selected private and public organizations in Nigeria, in order to seek permission to administer the measuring scales and virtually intimate them with the purpose of the study. All aspects of the questionnaire were explained to the respondents. The researcher through the help of the Director of Human Resource Management was able to administer the questionnaire with ease. However, it took the researcher a period of six weeks to administer and retrieve the distributed measuring scales due to geographical location of South-Western Nigeria. Meanwhile, out of 258 copies of questionnaire administered in the selected organizations, 240 completely filled copies of the questionnaire were utilized for the purpose of the study

\subsubsection{Data Analysis.}

The data collected through the questionnaire was analyzed using percentage and frequency counts for demographic information about the respondents. However, hypothesized research questions one and two were tested using Regression Analysis. Hypothesized research questions three and four were tested using t-test statistical method. All the five hypothesized research questions were tested at 0.05 alpha levels. 


\subsubsection{Results}

The results of the study were presented on the basis of the four hypothesized research questions generated for the study.

Research Question One: What is the combined influence of human capital formation programmes (computer skill training and conflict management skill training) to organizational commitment of workers?

Table 1: Summary of Regression Analysis Table on Combined Influence of the Selected Human Capital Formation Programmes to Organizational Commitment

\begin{tabular}{|c|c|c|c|c|c|c|}
\hline & A & $\begin{array}{r}\mathrm{R} \\
\mathrm{R} \mathrm{Squ} \\
\text { usted } \mathrm{I} \\
\text { andarc }\end{array}$ & $\begin{array}{l}0.658 \\
\text { are }=0.430 \\
\text { Square }=0.421 \\
\text { Error }=0.652\end{array}$ & & & \\
\hline & & & OVA & & & \\
\hline & Sum of Squares & Df & Mean Square & $\mathbf{F}$ & $\mathbf{P}$ & Remarks \\
\hline Regression & 32.453 & 2 & 7.546 & & & \\
\hline Residual & 45.612 & 237 & 0.659 & 12.376 & 0.000 & \\
\hline Total & 78.065 & 239 & & & & $\begin{array}{l}\text { Significan } \\
\text { t. } \\
(\mathrm{P}<0.05)\end{array}$ \\
\hline
\end{tabular}

Table 1 shows that all the human capital formation programmes (taken together) significantly influenced organizational commitment of workers. All the human capital formation programmes account for $43 \%$ of the total variance in job security. ( $\mathrm{R}$ Square $=0.430$ ). This implies that the human capital formation programmes are very important in ensuring organizational commitment.

Research Question Two: What is the strength of causation of predictor variables (Human capital formation programmes) on organizational commitment? 
Table 2: Summary of Regression Analysis Table on the Strength of Causation of

Predictor Variables (Human capital formation programmes) on

Organizational Commitment

\begin{tabular}{|c|c|c|c|c|c|c|}
\hline \multirow[t]{2}{*}{$\begin{array}{c}\text { Human Capital } \\
\text { Formation Programmes }\end{array}$} & \multicolumn{2}{|c|}{$\begin{array}{c}\text { Unstandardized } \\
\text { Coefficients }\end{array}$} & \multirow{2}{*}{$\begin{array}{l}\text { Standardized } \\
\text { Coefficients }\end{array}$} & \multirow[t]{2}{*}{$\mathrm{T}$} & \multirow[t]{2}{*}{ Sig. } & \multirow[t]{2}{*}{ Remarks } \\
\hline & $\begin{array}{c}\mathrm{B} \\
\text { Error }\end{array}$ & Std. & & & & \\
\hline Computer skill training & 0.432 & 0.302 & 0.167 & 1.345 & 0.001 & $\begin{array}{l}\text { Signific } \\
\text { ant } \\
(\mathrm{P}<0.05)\end{array}$ \\
\hline $\begin{array}{l}\text { Conflict management } \\
\text { Skill training }\end{array}$ & 0.379 & 0.311 & 0.234 & 1.413 & 0.000 & $\begin{array}{l}\text { Signific } \\
\text { ant } \\
(\mathrm{P}<0.05)\end{array}$ \\
\hline
\end{tabular}

Table 2 revealed the two independent variables (computer skill training, $\mathrm{t}=1.345$; $(\mathrm{P}<0.05)$ and conflict management skill training, $\mathrm{t}=1.345 ; \mathrm{P}<0.05)$ have significantly influenced organizational commitment of workers.

Research Question Three: Is there any significant gender differences in exposure of employees to human capital formation programmes?

Table 3: t-test Summary on Gender Differences in Human Capital Formation Programmes Exposure.

\begin{tabular}{|c|c|c|c|c|c|c|c|}
\hline $\begin{array}{l}\text { Human Capital } \\
\text { Formation Programmes }\end{array}$ & Gender & $\mathrm{N}$ & Mean & $\mathrm{SD}$ & $\mathrm{T}$ & $\mathrm{P}$ & Remark \\
\hline \multirow[t]{2}{*}{ Computer skill training } & Male & 144 & 1.1623 & .3327 & \multirow[t]{2}{*}{-1.554} & \multirow[t]{2}{*}{0.754} & \multirow{2}{*}{$\begin{array}{c}\text { Not } \\
\text { Significant }\end{array}$} \\
\hline & Female & 96 & 1.2711 & .4782 & & & \\
\hline \multirow{2}{*}{$\begin{array}{l}\text { Conflict management } \\
\text { Skill training }\end{array}$} & Male & 144 & 1.3763 & .4132 & \multirow[t]{2}{*}{1.468} & \multirow[t]{2}{*}{0.646} & \multirow{2}{*}{$\begin{array}{c}\text { Not } \\
\text { Significant }\end{array}$} \\
\hline & Female & 96 & 1.3287 & .4875 & & & \\
\hline \multirow[t]{2}{*}{ Both organization types } & Male & 144 & 1.3678 & .5128 & \multirow[t]{2}{*}{-0.211} & \multirow[t]{2}{*}{0.855} & \multirow{2}{*}{$\begin{array}{c}\text { Not } \\
\text { Significant }\end{array}$} \\
\hline & Female & 96 & 1.4679 & .4982 & & & \\
\hline
\end{tabular}

Table 3 shows that there is no significant difference between male and female employees exposure to each of the human capital formation programmes. The finding revealed that there was no gender discrimination in the selection of workers for both on-the-job and off-the-job human capital formation programmes in each of the selected organizations in Nigeria. 
Research Question four: Is there any significant gender difference in organizational commitment on the basis of exposure of respondents to human capital formation programmes?

Table 3 revealed that there was no significant difference in the level of both male and female workers' participation in human capital formation programmes in both public and private organizations selected for the study.

Research Question five: Is there any significant gender difference in organizational commitment on the basis of exposure of respondents to human capital formation programmes?

Table 3: Summary of t-test on Analysis on Comparison of Male and Female Employees' Organizational Commitment based on their Participation in Human Capital Formation Programmes.

\begin{tabular}{|c|c|c|c|c|c|c|c|c|}
\hline & $\mathrm{N}$ & Mean & $\begin{array}{l}\text { Std } \\
\text { Dev. }\end{array}$ & $\begin{array}{l}\text { Std } \\
\text { Error }\end{array}$ & $\mathrm{df}$ & $\mathrm{t}$ & $\mathrm{p}$ & Remark \\
\hline Male & 144 & 10.213 & 8.564 & 0.432 & \multirow[b]{2}{*}{238} & \multirow[b]{2}{*}{6,98} & \multirow[b]{2}{*}{0.000} & \multirow[b]{2}{*}{$*$} \\
\hline Female & 96 & 9.435 & 7.117 & 0.330 & & & & \\
\hline
\end{tabular}

\section{* Significant $(\mathrm{P}<0.05)$}

As indicated in table 3 , the finding revealed that there is a significant difference between male and female workers' organizational commitment based on their participation in human capital formation programmes

\subsection{Discussion of Findings}

This study investigated the influence of human capital formation programmes on organizational commitment among industrial workers in South-West Nigeria. The finding of the study revealed that human capital formation programmes have directly influenced organizational commitment among industrial workers. Finding further indicates that all human capital formation programmes account for $43 \%$ of the total variance in organizational commitment. This implies that human capital formation programmes are very important factors in ensuring organizational commitment among industrial workers in selected work organizations. The finding corroborates Cole (2011); Armstrong (2002), Steinmetz (1990), Koehorst and Verhoevon (2002), Akintayo (2009), Keep and Mayhew (1999) and Kenny (2011) who reported a significant relationship between manpower development programmes and reduction in labour turnover.

Moreover, finding has also revealed the strength of causation of predictor variables (computer skill training and conflict management skill training) on organizational commitment among workers in selected work organizations. The finding tallies with Olaniyi (2010), Ichmowski and Prennushi(1997) and Peterson (2004) who submit that manpower 
training programmes, especially the labour relations and interpersonal treatment skill had significant influenced workers' good placement on the job, since the training programmes cover all aspects of employment relations.

Furthermore, the finding established that human capital formation programmes (computer skill training and conflict management skill training) independently predict organizational commitment among industrial workers. It was also found that computer skill training and conflict management skill training programmes have relative contribution to organizational commitment. This finding shows that these two variables are inevitable factors to be considered while measuring the influences of human capital formation programmes on organizational commitment among workers in selected work organizations. The finding of the study tallies with Johnbul (2001), Peterson (2004), Rita (2004), Kingsley (2011) who submit that labour relations and interpersonal skill training programmes have significantly influenced workers' sustainable relationship with the employer. The findings disagree with Reach (1999), Milkman (1997), Zymelman (2000) and Akintayo (2009) who reported that human resource development programmes tend to influences workers job performance effectiveness and could possibly lead to labour turnover resulting from occupational mobility.

The third and fourth hypothesized research questions revealed that there is no significant difference between male and female employees' exposure to each of the human capital formation programmes among workers in both public and private organizations selected for the study. This implies that male and female workers were encouraged to undergo the same human capital formation programmes in both public and private work organizations without gender discrimination. The finding of the study corroborates Keep and Mayhew (1999), Lesile and Russel (1998), Steinmetz (1990), Koehorst and Verhoevon (2002), and Oloyede (2000) who reported that human resource development programmes tend to foster occupational mobility of workers, sustainability of employer's confidence and preference of both male and female trained workers. The finding implies that were no significant gender difference in the level of workers participation in human capital formation programmes. In essence, both male and female respondents have equal chance of participation in human capital formation programmes devoid of gender discrimination in selected work organizations.

\subsubsection{Conclusion}

The findings of the study established that human capital formation programmes have directly influenced workers` organizational commitment. The finding revealed that even in this era of computer age, the human side of the enterprise should not be underrated. The quality of human capital in any organization determines the productivity and profitability of that organization. The finding implies that human capital formation programmes are worthy of huge investment especially on the side of the employer. The ultimate dividend is increased productivity, resulting to maximization of profit and therefore enhances job commitment. The finding further implies that the employers need to bear the cost of human capital formation programmes and should be concern to ensure that training facilities are modernized and over hauled from time to time in order to foster organizational commitment on the part of 


\section{Macrothink \\ International Journal of Human Resource Studies \\ ISSN 2162-3058 \\ 2012, Vol. 2, No. 4}

the workers and competitive advantages on the part of the organization itself.

\subsubsection{Recommendations}

Based on the findings of the study, and bearing in mind the dynamism of Nigerian working environment, it is recommended that:

i. Human capital formation programmes should be given priority by all establishments in order to forestall organizational commitment for all levels of workers. Also, training needs of the organization as well as that of workers must be identified before making recommendations for training. This will possibly foster specialization and encourage technical-driven training in work organizations with corresponding effects on workers commitment to organizational goal achievement.

ii. Human resource development policies should be well defined and be entrenched in the mission statement of all work organizations in Nigeria, in order to foster equity and promotional skill acquisition. The development policies of any goal-oriented organization should emphasis the need to be organizing human capital formation programmes for all levels of workers on continuous basis in order to provide opportunity for workers towards updating their skills, improving their performance on the job and virtually sustained their job commitment.

iii. Opportunity for participation in human capital formation programmes must be available to all staffers devoid of discrimination and should be sponsored solely by the employer of labour. In essence, there should not be gender or tribal discrimination in the selection of workers for participation in human capital formation programmes. This will definitely ensure worker' organizational commitment vis-à-vis organizational goal achievement in work organizations. 


\subsubsection{References}

Akintayo, D.I. (2009). Influence of human resource development programmes on perceived workers ' productivity in work organizations in Nigeria. Journal of Educational Administration, vol.9(2), 45-56.

Akintayo, M.O. (2007). Concept and practice of continuing education. In Akinpelu J.A., Okedara, J.T. and Omolewa, M.A (Ed) Language and Adult Education, Ibadan University Press.

Akintayo, D.I. and Lawrence (2009). Trends in professional education and workers development in Nigeria. Journal of Educational Research and Development, 6, (2), 21-30.

Akintimile, K.A.(2002). Cost of on-the-job training: Whose responsibility? Pape presented at the 2002 National Workshop on Continuing Education Programmes. University of Ibadan Conference Centre, Ibadan 1-7.

Armstrong, M. (2002). A handbook of human resource management practice. $7^{\text {th }}$ edition, London: Kogan Page Limited.

Bentein, K. Vandenberghe, C. V. R. \& Stinglhamber, F. (2005). The role of change in the relationship between commitment and turnover: A latent growth modeling approach. Journal of Applied Psychology, 90, 468-482.

Shimry, L.L and Leohard, M.W (2002).Training in industry: The management of Learning. London: Tanistock Publications.

Cole. P.K.(20`). Personnel management of people at work. New York: Macmillan.

Collins F.H. (2010). Human capital and development in organizations: Issues and challenges. Journal of Organizational Development and Productivity, vol. 11 (2), 46-55.

Kolawole, S.K. (2010). Training needs in industrializing society: The Nigeria experience. Paper presented at the Commonwealth Regional Seminar on Technical Education, University of Ibadan.

Caleb. O.A(2010). Human resource development: An introduction. $1^{\text {st }}$ edition, Macmillan Publisher.

Friar, K.L. (2004) .Training brochure: United Nations handbook on training in the public 
service. New York: Prentice Hall, 15-25.

Ichniowski, C.S. and Prennushi, G (1997). The effect pf human resource management practices on productivity: A study pf Steel Finishing Lines. The American Economic Review, 87 (1), 291-313.

Johnbul, A.E. (2001).On training and the learning process. Englewood Cliff: Prentice Hall.

Keep, E.and Mayhew, K.(1999). The assessment, knowledge, skills and competitiveness. Oxford Review Of Economic Policy, 15 (1), 1-15.

Kenny, U.P. (2011). Understanding the relevance of human capital formation in developing countries. Journal of Career Counseling and Development, vol. 7 (1), 2132

Kingsley, J.K. (2011). Dimensions in human capital formation and organizational productivity. Journal of Education Research and Development, vol. 11 (3), 45-53.

Koehorst L.H. and Verhoevon, D.B. (2002). Training programme in industry: Issues and prospects. Journal of Social Psychology, 29, 483-489.

Lesile, E. and Russell, B. (1998). Employment security and job loss: Lesson from Canada's National Railways (1956-1995). http//www.historycooperative.org/ journal/lit/51/ehrlich.html.

Phillips and Thomas, E.O. (2007). Labour economic and employment relations. New Jersey: Prentice Hall.

Jaros, S. Jermier, J. Koehler, J. \& Sincich, T. (2004). Effects of continuance, affective, and moral commitment on the withdrawal process: An evaluation of eight structural equations models. Academy of Management Journal, 36, 951-995.

Kerr, L P. (2001). Linking VET to productivity difference: An evaluation of the Paris programme and its implication for Australia. Centre for the Economics of Education and Training working paper, 18.

Meyer, J. P. and Allen, N. J. (2003). Commitment to organizations and occupations: Extension and test of a three-component conceptualization. Journal of Applied Psychology, 78, 538-551. 
Meyer J.P., Allen, N.J and Smith, S.T. (1993). Affective, continuance and normative commitment to the organization: An examination of construct validity. Journal of Vocational Behaviour, 49 (3), 252-276.

Meyer, J. P. Allen, N. J. Gellatly, I. R., Goffin, L. \& Jackson, N.A. (2000).

Affective and continuance commitment to the organization: Evaluations of measures and analyses of concurrent and time-lagged relations. Journal of Applied Psychology, 75, 710-720.

Milkman, P.O. (1997). Workers education and development. Journal of Research and Development in Education, 16, 60-65.

Mowday, R. T., Porter, L.W., and Steers, R.M. (2003). Viewing turnover from the perspective of those who remain: The relationship of job attitudes to attributions of the cause of turnover. Journal of Applied Psychology, 66,120-123.

Odia, G.K. (2007). Capacity building and the future of business organization in Kenya. Journal of Human Resource Management, vol 17 (1), 133-122.

Olaniyi, A.A. (2010). Human resource training and development in work organization: Case study of Nigerian Breweries Plc, Unpublished PhD Thesist, University of Lagos, Lagos

Oloyede, D, O. (2000). Human resource development and productivity in unionized and non-unionized industries in Oyo State. Unpublished PhD Thesis, University of Ibadan, Ibadan.

Williams, O.P. (2010).Diversity in workers empowerment for competitive advantage in work organization. Paper presented at National Workshop on Human Resource Development, organized by Nigeria Institute of Personnel Management at Abuja, Nigeria, October.

Omole, M.A.L. (2004). Training and re-training: A variable of technological development. .Journal of Industrial Education, 14 (2), 76-85

Rita, D.V. (2004). Skill training and work organization in American establishment. Industrial Relations, 34 (2), 125-146.

Peterson, M.S...(2004). Leadership education and workers proficiency at workplace Journal of Management Psychology, 21 (2), 31-40

Reach, S. (1999). Personnel management of people at work. New York: Macmillan. 
Spector, P. E. (2000). Industrial and organizational psychology: Research and practice ( 2 Ed.). USA: John Wiley \& Sons.

Willington, T.H. (2003). Effective reaction to workers education: An exploration of the learning effectiveness. Journal Applied Behavioural Sciences. 35, 102-117.

Shadare, O.A (2002). Assessment of data-based industrial instrument strategy in work organizations in Nigeria: Case study of Nigeria Telecommunication Plc, Unpublished MSc Project, University of Ibadan, Ibadan.

Steinmetz, C.S (1990). The history of training and development. New York: Mc Hill Book Company, 1-6

Zymelman, M. (2000). The economic evaluation of vocational training programmes. London: The John Hopkins University Press, 12-26. 